\title{
EFFECT OF LACTOCOCCUS LACTIS VS. LACTOBACILLUS SPP. BACTERIA ON CHICKEN BODY WEIGHT, MORTALITY, FEED CONVERSION AND CARCASS QUALITY*
}

\author{
Franciszek Brzóska', Bogdan Śliwiński ${ }^{1}$, Krystyna Stecka ${ }^{2}$ \\ 'Department of Animal Nutrition and Feed Science, National Research Institute of Animal Production, \\ 32-083 Balice n. Kraków, Poland \\ ${ }^{2}$ Institute of Agricultural and Food Biotechnology, Rakowiecka 36, 02-532 Warszawa, Poland
}

\begin{abstract}
A total of 608 Ross 308 broiler chickens of both sexes were studied to determine the effect of Lactococcus lactis 847 bacteria compared to probiotic bacteria Lactobacillus delbruecki 838 and Lactobacillus plantarum 837 on body weight, feed consumption and conversion, mortality, dressing percentage, postmortem carcass traits, composition of breast muscle tissue, and blood plasma traits. Feeding diets with bacteria to chickens did not increase body weight at $\mathbf{4 2}$ days of age or improve feed conversion compared to control chickens. It significantly reduced chicken mortality compared to the control group, from $3.3 \%$ to $1.4 \%(P<0.01)$. No significant differences were found in feed consumption and conversion. There were no significant differences in the weight of carcasses and their parts. Lactococcus lactis 847 and Lactobacillus plantarum 837 bacteria significantly increased dressing percentage $(\mathbf{P}<0.05)$. Lactococcus lactis 847 significantly increased liver weight $(\mathrm{P}<0.05)$. No significant differences were observed in carcass fatness, and in the dry matter, protein and fat content of breast muscles. Feeding diet with Lactobacillus plantarum 837 to chickens significantly decreased plasma triglyceride levels, and feeding diet with Lactobacillus delbruecki 838 and Lactobacillus plantarum 837 significantly decreased the level of high-density cholesterol $(\mathrm{P}<0.05)$. In conclusion, Lactococcus lactis 847 bacteria in diet significantly reduce losses due to digestive disorders while having no effect on the quantity and proportion of saleable cuts in the carcass, the composition of breast muscles and basic blood parameters.
\end{abstract}

Key words: lactic acid bacteria, chicken, body weight, mortality, feed conversion, blood metabolites

Lactic acid microorganisms include strains of Lactobacillus Spp., Enterococcus Spp., Streptococcus Spp. and Bacillus Spp. bacteria. Of these, Lactobacillus Spp. are used most often in probiotic additives for poultry. Lactococcus Spp., formerly known as Streptococcus Spp., include Lactococcus lactis ssp. cremoris and Lactococcus lactis ssp. lactis. These gram-positive cocci are non-sporing, non-motile,

\footnotetext{
*This study was financed from statutory activity 05-03.02.1.
} 
and occur singly or in short chains. They have a homofermentative metabolism and produce L $(+)$ lactic acid from lactose. They can metabolize other simple sugars. In the dairy industry, they are used to produce buttermilk and cheese. Genetically modified Lactococcus lactis are finding application in the treatment of human diseases (Prost, 1999). Probiotic bacteria applied in animal nutrition originate from different materials, including fermented feeds and vegetables, fermented milk, and human and animal digesta (Grela and Semeniuk, 1999). The beneficial effects of probiotic bacteria on the digestive tract and performance of chickens were reported by many studies (Brzóska et al., 1999; Simon et al., 2001; Ghadban, 2002; Brzóska et al., 2005). Little information is available on the probiotic activity of Lactococcus lactis. These bacteria are held in the collection of microorganisms owned by the Institute of Agricultural and Food Biotechnology in Warsaw. Laboratory tests showed that Lactococcus lactis 847 are similar to Lactobacillus Spp. in terms of the metabolism of glucose and lactose to lactic acid (Grzybowski et al., 1998). This suggests that they have similar acidifying power and action on pathogenic bacteria of the digestive tract of animals.

It was hypothesized that probiotic properties of Lactococcus lactis may be similar to those of well-known strains of probiotic bacteria of the genus Lactobacilus Spp., including Lactobacillus delbruecki 838 and Lactobacillus plantarum 837.

To test this hypothesis, a feeding trial was conducted with broiler chickens to determine the effect of Lactococcus lactis supplementation on rearing performance of broilers, including their body weight and mortality, as well as carcass quality, breast muscle composition and key blood metabolites.

\section{Material and methods}

A feeding trial was conducted with 608 straight-run Ross 308 broiler chickens. Initial body weight was determined for 40 randomly chosen chicks. Birds were randomly divided into 4 groups, each replicated 4 times with 152 chickens per group and 38 chickens per replicate. The random selection ensured that both sexes were represented in each group and replicate. The one-day-old chicks had a body weight of $41.8 \pm 2.5 \mathrm{~g}$. Birds were housed on deciduous litter in metal cages, at a stocking density of $18 \mathrm{birds} / \mathrm{m}^{2}$, with approximately $35 \mathrm{~kg}$ live bird weight $/ \mathrm{m}^{2}$ at the termination of the experiment. Chickens were fed a poultry compound feedingstuff that contained ground maize, ground wheat and soybean meal as the principal components (Table 1). Feed mixtures contained a prebiotic in the form of mannan oligosaccharide (BIOMOS, Alltech-Polska Co.; $1.5 \mathrm{~g} / \mathrm{kg}$ mixture) and an acidifier (Acidomix AFG, Novus Deutschland GmbH; $6 \mathrm{~g} / \mathrm{kg}$ mixture). Probiotic bacteria (4 million cells/bird/day) were administered in drinking water at $6,7,8,21,22$ and 23 days of age. Chickens were vaccinated against infectious bursal disease on day 5 and against fowl plague on day 12. Birds received Vitazol vitamin preparation 8 times. Nutrients in the diets were determined chemically (AOAC, 1990). Chickens were fed starter and grower diets ad libitum. Water was provided in nipple drinkers (days 
1 to 21 ) and in trough waterers (days 22 to 42 ). Feed consumption was recorded per group and replicate, feed conversion ( $\mathrm{kg} / \mathrm{kg}$ gain) was calculated, and mortality was monitored. Chickens were weighed at 21 and 42 days of age, after a 24-hour feed withdrawal. On day 43, 10 birds ( 5 male and 5 female) were chosen from each group (40 birds in total). The project was accepted by the Local Ethic Committee. After determination of slaughter weight, birds were stunned and slaughtered by decapitation. During slaughter, blood samples were collected into heparinized tubes and centrifuged to obtain plasma. Fresh plasma samples were used to analyse blood glucose concentration. Frozen plasma was thawed to determine total protein, triglycerides, total cholesterol and high density lipoproteins (HDL). Blood components were analysed using Cormay Diagnostic kits. Measurements were made with a Beckman DU 640 spectrophotometer.

Table 1. Feed materials and additives, and nutritive value of starter and grower diets $(\mathrm{g} / \mathrm{kg})$

\begin{tabular}{l|c|c}
\hline \multirow{2}{*}{ Item } & \multicolumn{2}{|c}{ Diet } \\
\cline { 2 - 3 } & starter, days 1-21 & grower, days 22-42 \\
\hline Feed components: & & \\
maize & 26.90 & 34.40 \\
wheat & 28.60 & 23.60 \\
soybean meal & 32.00 & 28.50 \\
rapeseed meal & 4.00 & 4.00 \\
herb mixture & 2.00 & 2.50 \\
dicalcium phosphate & 1.70 & 1.70 \\
ground limestone & 0.60 & 0.60 \\
sodium chloride & 0.35 & 0.35 \\
L-lysine HCL (78\%) & 0.11 & 0.11 \\
DL-methionine (99\%) & 0.14 & 0.14 \\
vitamin-mineral premix ${ }^{1-2)}$ & 0.50 & 0.50 \\
Biomos (mannan oligosaccharide) & 0.10 & 0.10 \\
Acidomix & 0.006 & 0.006 \\
Nutrients per kg of feed dry matter: & & \\
crude protein (g) & 228.4 & 222.2 \\
crude fat (g) & 6.92 & 6.79 \\
N-free extractives (g) & 607.1 & 599.6 \\
water-soluble carbohydrates (g) & 51.8 & 50.8 \\
crude ash (g) & 5.90 & 6.85 \\
Lysine (g) & 10.70 & 10.74 \\
Methionine-Cystine (g) & 6.80 & 6.71 \\
calcium (g) & 8.3 & 8.5 \\
phosphorus (g) & 6.8 & 6.9 \\
metabolizable energy (MJ) & 12.55 & 12.49 \\
\hline
\end{tabular}

1) $1 \mathrm{~kg}$ starter diet supplemented with: vit. A - $13500 \mathrm{IU}$; vit. D - $3600 \mathrm{IU}$; vit. E - $45 \mathrm{mg}$; vit. $\mathrm{B}_{1}-3.25$ $\mathrm{mg}$; vit. $\mathrm{B}_{2}-7.5 \mathrm{mg}$; vit. $\mathrm{B}_{6}-5 \mathrm{mg}$; vit. $\mathrm{B}_{12}-0.0325 \mathrm{mg}$; vit. $\mathrm{K}_{3}-3 \mathrm{mg}$; biotin $-0.15 \mathrm{mg}$; nicotinic acid $45 \mathrm{mg}$; calcium pantothenate $-15 \mathrm{mg}$; folic acid - $1.5 \mathrm{mg}$; choline chloride - $100 \mathrm{mg}$; $\mathrm{Mn}-100 \mathrm{mg}$; $\mathrm{Cu}-$ $1.75 \mathrm{mg}$; Fe - $76.5 \mathrm{mg}$; Se - $0.275 \mathrm{mg}$; I $1 \mathrm{mg}$; Zn - 75 mg; Co - $0.4 \mathrm{mg}$; Endox (antioxidant) - $125 \mathrm{mg}$; Sincox (coccidiostat) $-1 \mathrm{~g}$ and calcium $-0.679 \mathrm{~g}$.

2) $1 \mathrm{~kg}$ grower diet supplemented with: vit. A - $12000 \mathrm{IU}$; vit. D - $3250 \mathrm{IU}$; vit. E - $40 \mathrm{mg}$; vit. $\mathrm{B}_{1}-2$ $\mathrm{mg}$; vit. $\mathrm{B}_{2}-7.25 \mathrm{mg}$; vit. $\mathrm{B}_{6}-4.25 \mathrm{mg}$; vit. $\mathrm{B}_{12}-0.03 \mathrm{mg}$; vit. $\mathrm{K}_{3}-2.25 \mathrm{mg}$; biotin $-0.1 \mathrm{mg}$; nicotinic acid $40 \mathrm{mg}$; calcium pantothenate $-12 \mathrm{mg}$; folic acid - $1.0 \mathrm{mg}$; choline chloride - $450 \mathrm{mg}$; $\mathrm{Mn}-100 \mathrm{mg}$; $\mathrm{Cu}-$ 1.75 mg; Fe - 76.5 mg; Se - 0.275 mg; I - 1 mg; Zn - 75 mg; Co - 0.4 mg; Endox (antioxidant) - 125 mg; Sincox (coccidiostat) $-1 \mathrm{~g}$ and calcium $-0.79 \mathrm{~g}$. 
Birds were slaughtered, exsanguinated and scalded, after which the carcasses were mechanically defeathered and eviscerated. Carcasses, stomach, liver, feet, omental fat and depot fat from the posterior part of the body cavity were weighed. Both types of fat were referred to as depot fat. Carcasses were chilled in a cold room at $5^{\circ} \mathrm{C}$ for $24 \mathrm{~h}$. The next day, carcasses were dissected using a method described by Zgłobica and Różycka (1972). The weight of breast muscles, leg muscles, depot fat, skin and leg bones was determined. The weight of individual carcass parts was related to total carcass weight and expressed in percent. Breast muscles (100 g) were taken from the right carcass side, ground and frozen at $-18^{\circ} \mathrm{C}$ for chemical analysis. After thawing, the samples were analysed for dry matter, crude protein and crude fat. The analyses were performed with standard methods used at the Central Laboratory of the National Research Institute of Animal Production, which is accredited by the Polish Centre for Accreditation, accreditation no. AB 512 (AOAC, 1990).

All data were subjected to 1-way ANOVA using SPSS 15.0 for Windows. Mean values of treatment groups were compared using Duncan's multiple range test with $\mathrm{P}<0.01$ and $\mathrm{P}<0.05$ considered statistically significant.

\section{Results}

The body weight of 42-day-old chickens, including that of chickens supplemented with Lactococcus lactis 847 , did not differ significantly from the unsupplemented chickens in the control group. Probiotic bacteria, including Lactococcus lactis 847 , significantly reduced mortality, from about 33.3/1000 chickens in the control group to $12.4 / 1000$ chickens in the experimental groups $(\mathrm{P}<0.01)$. No significant differences were found in feed consumption and conversion between the experimental and control groups. Lactococcus lactis 847 and Lactobacillus plantarum 837 bacteria significantly increased dressing percentage $(\mathrm{P}<0.05)$. There were no significant differences in warm and cold carcass weight, in saleable cuts, and in their percentage in total carcass weight. The group receiving Lactococcus lactis 847 had significantly increased liver weight compared to the group receiving Lactobacillus plantarum $837(\mathrm{P}<0.05)$. There were no differences in stomach weight. Depot fat was highest for carcasses from chickens receiving Lactococcus lactis 847 , although it did not differ significantly from the other groups. No significant differences were found in the dry matter, protein and fat content of breast muscles. Feeding Lactobacillus plantarum 837 significantly decreased plasma triglyceride levels, and giving probiotic bacteria Lactobacillus delbruecki 838 and Lactobacillus plantarum 837 to the chickens significantly decreased the level of HDL cholesterol $(\mathrm{P}<0.05)$. Male birds had significantly higher body weight and weight of different saleable cuts compared to female birds $(\mathrm{P}<0.01)$. Female carcasses were characterized by a higher content of depot fat and a higher proportion of depot fat in carcass weight $(\mathrm{P}<0.01)$. No differences were observed in the chemical composition of breast muscles in both sexes. The blood plasma 
of male birds had higher levels of glucose and total cholesterol $(\mathrm{P}<0.01)$, with no significant differences in the total protein and triglyceride content, compared to the female group.

Table 2. Body weight of broilers, mortality and feed conversion

\begin{tabular}{l|c|c|c|c|c}
\hline \multirow{2}{*}{\multicolumn{1}{c|}{ Item }} & \multicolumn{4}{c|}{ Dietary factor } & \multirow{2}{*}{ SEM } \\
\cline { 2 - 5 } & CON & LL & LD & LP & \\
\hline Body weight, day 21 (g) & $748 \mathrm{ab}$ & $775 \mathrm{~b}$ & $727 \mathrm{a}$ & $762 \mathrm{~b}$ & 4 \\
Body weight, day 42 (g) & 2458 & 2476 & 2435 & 2456 & 14 \\
Mortality (\%) & $3.3 \mathrm{Aa}$ & $1.4 \mathrm{Bb}$ & $1.4 \mathrm{Bb}$ & $1.4 \mathrm{Bb}$ & 0.4 \\
Feed consumption, day 21 (kg) & 1.06 & 1.06 & 1.06 & 1.06 & 0.22 \\
Feed consumption, day 42 (kg) & 4.42 & 4.54 & 4.39 & 4.54 & 0.26 \\
Feed conversion (kg/kg gain) & 1.80 & 1.83 & 1.80 & 1.85 & 0.10 \\
European Efficiency Index (points) & 319 & 322 & 324 & 315 & 13 \\
\hline
\end{tabular}

$\mathrm{a}, \mathrm{b}, \mathrm{c}-$ values in rows with different letters differ significantly $(\mathrm{P}<0.05)$.

$\mathrm{A}, \mathrm{B}, \mathrm{C}-$ values in rows with different letters differ significantly $(\mathrm{P}<0.01)$.

CON - control.

LL - Lactococcus lactis 847.

LD - Lactobacillus delbruecki 838.

LP - Lactobacillus plantarum 837.

SEM - standard error of the mean.

BWG - body weight gain.

Table 3. Carcass weight, dressing percentage, weight of breast and leg muscles

\begin{tabular}{|c|c|c|c|c|c|}
\hline \multirow{2}{*}{ Item } & \multicolumn{4}{|c|}{ Dietary factor } & \multirow{2}{*}{ SEM } \\
\hline & $\mathrm{CON}$ & LL & LD & LP & \\
\hline Weight at slaughter (g) & 2492 & 2510 & 2481 & 2486 & 30 \\
\hline Warm carcass weight $(\mathrm{g})$ & 1834 & 1863 & 1835 & 1863 & 25 \\
\hline Cold carcass weight (g) & 1794 & 1820 & 1791 & 1821 & 24 \\
\hline Dressing percentage & $73.60 \mathrm{a}$ & $74.22 \mathrm{~b}$ & $73.96 \mathrm{a}$ & $74.94 \mathrm{~b}$ & 0.14 \\
\hline \multicolumn{6}{|l|}{ In carcasses $(\mathrm{g})$ : } \\
\hline breast muscles & 243.3 & 250.1 & 247.2 & 258.6 & 3.1 \\
\hline leg muscles & 197.2 & 196.1 & 192.1 & 193.6 & 0.18 \\
\hline stomach & 27.2 & 27.1 & 27.1 & 27.5 & 0.03 \\
\hline liver & $44.6 \mathrm{ab}$ & $49.02 \mathrm{~b}$ & $47.7 \mathrm{ab}$ & $41.3 \mathrm{a}$ & 1.0 \\
\hline depot fat & 31.4 & 40.7 & 34.0 & 31.1 & 1.0 \\
\hline \multicolumn{6}{|l|}{ In carcasses $(\%)$ : } \\
\hline breast muscles & 27.20 & 27.52 & 27.67 & 28.47 & 3.2 \\
\hline leg muscle & 21.95 & 21.51 & 21.23 & 21.99 & 0.7 \\
\hline stomach & 1.5 & 1.5 & 1.5 & 1.5 & 0.03 \\
\hline liver & $2.3 \mathrm{ab}$ & $2.7 \mathrm{c}$ & $2.6 \mathrm{bc}$ & $2.2 \mathrm{a}$ & 0.1 \\
\hline depot fat & 1.9 & 2.3 & 1.9 & 1.7 & 0.1 \\
\hline
\end{tabular}

For explanations, see Table 2.

$\mathrm{CC}$ - cold carcass.

$\mathrm{WC}$ - warm carcass. 
Table 4. Nutrient components in breast muscle and blood serum parameters

\begin{tabular}{|c|c|c|c|c|c|}
\hline \multirow{2}{*}{ Item } & \multicolumn{4}{|c|}{ Dietary factor } & \multirow{2}{*}{ SEM } \\
\hline & $\mathrm{CON}$ & $\mathrm{LL}$ & LD & LP & \\
\hline \multicolumn{6}{|c|}{ Chemical composition of meat (\% DM): } \\
\hline dry matter & 25.00 & 25.05 & 24.90 & 24.70 & 0.64 \\
\hline crude protein & 23.57 & 23.71 & 23.42 & 23.51 & 0.72 \\
\hline ether extract & 1.06 & 1.02 & 1.03 & 1.09 & 0.22 \\
\hline \multicolumn{6}{|c|}{ Blood serum parameters $(\mathrm{mg} / \mathrm{dl})$ : } \\
\hline glucose & 241.3 & 253.3 & 254.2 & 254.9 & 17.4 \\
\hline total protein & 3.35 & 3.43 & 3.38 & 3.26 & 0.03 \\
\hline triglycerides & $30.1 \mathrm{~b}$ & $30.9 \mathrm{~b}$ & $35.6 \mathrm{~b}$ & $25.7 \mathrm{a}$ & 1.4 \\
\hline total cholesterol & $132.2 \mathrm{~b}$ & $131.2 \mathrm{~b}$ & $120.7 \mathrm{a}$ & $119.0 \mathrm{a}$ & 2.3 \\
\hline HDL & $102.0 \mathrm{~b}$ & $97.8 \mathrm{~b}$ & $91.8 \mathrm{a}$ & $91.1 \mathrm{a}$ & 3.5 \\
\hline
\end{tabular}

a, b, c - values in rows with different letters differ significantly $(\mathrm{P}<0.05)$.

For explanations, see Table 2.

Table 5. Carcass weight, dressing percentage, weight of breast and leg muscles according to sex of chicken

\begin{tabular}{l|c|c|c}
\hline \multirow{2}{*}{ Item } & \multicolumn{2}{c|}{ Sex } & \multirow{2}{*}{ SEM } \\
\cline { 2 - 3 } & male & female & \\
\hline Weight at slaughter (g) & $2641 \mathrm{aA}$ & $2272 \mathrm{bB}$ & 30 \\
Warm carcass weight (g) & $1988 \mathrm{aA}$ & $1713 \mathrm{bB}$ & 25 \\
Cold carcass weight (g) & $1941 \mathrm{aA}$ & $1676 \mathrm{bB}$ & 24 \\
Dressing percentage & 75.27 & 75.40 & 0.14 \\
In carcasses (g): & & & 3.1 \\
breast muscles (g CC) & $265.4 \mathrm{aA}$ & $236.0 \mathrm{bB}$ & 0.18 \\
leg muscles (g CC) & $212.9 \mathrm{aA}$ & $175.9 \mathrm{bB}$ & 0.03 \\
stomach (g WC) & $29.3 \mathrm{aA}$ & $25.2 \mathrm{bB}$ & 1.0 \\
liver (g WC) & $49.1 \mathrm{aA}$ & $42.5 \mathrm{bB}$ & 1.0 \\
depot fat (g CC) & 34.0 & 2.1 & 3.2 \\
In carcasses (\%): & & & 0.7 \\
breast muscles & 27.4 & 28.2 & 0.03 \\
leg muscles & $21.9 \mathrm{aA}$ & $21.0 \mathrm{bB}$ & 0.1 \\
stomach & 1.5 & 1.5 & 0.1 \\
liver & 2.4 & 2.5 & 2.1 \\
depot fat & 1.8 & & \\
\hline
\end{tabular}

For explanations, see Table 2.

Table 6. Nutrient components in breast muscle and blood serum parameters according to sex of chicken

\begin{tabular}{|c|c|c|c|}
\hline \multirow{2}{*}{ Item } & \multicolumn{2}{|c|}{ Sex } & \multirow{2}{*}{ SEM } \\
\hline & male & female & \\
\hline \multicolumn{4}{|c|}{ Chemical composition of meat (\% DM): } \\
\hline dry matter & 24.94 & 24.86 & 0.64 \\
\hline crude protein & 23.59 & 23.51 & 0.72 \\
\hline ether extract & 1.06 & 1.00 & 0.22 \\
\hline \multicolumn{4}{|c|}{ Blood serum parameters (mg/dl): } \\
\hline glucose & $257.5 \mathrm{aA}$ & $247.0 \mathrm{aB}$ & 17.4 \\
\hline total protein & 3.31 & 3.34 & 0.03 \\
\hline triglycerides & 30.3 & 31.6 & 1.4 \\
\hline total cholesterol & $132.7 \mathrm{aA}$ & $118.7 \mathrm{aB}$ & 2.3 \\
\hline HDL & $99.1 \mathrm{aA}$ & $90.4 \mathrm{bB}$ & 3.5 \\
\hline
\end{tabular}

a, b, c - values in rows with different letters differ significantly $(\mathrm{P}<0.05)$.

For explanations, see Table 2. 


\section{Discussion}

In light of the research reported in the literature, probiotic bacteria are attributed with important functions, including stimulation of immunity, acidification of the gastrointestinal tract through fermentation of sugars into lactic acid, production of hydrogen peroxide, and synthesis of bacteriocins (Fuller, 1989; Saarela et al., 2000; Śliżewska et al., 2006). Other publications point to the anticarcinogenic effect of probiotic bacteria on the digestive tract (Rafter, 1995; Kabit et al., 1997; Coconnier et al., 1998). Stimulating the acquired immune system and increasing resistance to pathogenic bacteria during the first days of life is the body's response to foreign bacterial protein supplied by the food (McCracken and Gaskins, 1999; Vitini et al., 2001; Koenen et al., 2004). This synthesizes antibodies that circulate in the blood system and are directed against pathogenic bacteria, such as Salmonella, Shigella, Staphylococcus, Listeria, Campylobacter, Yersinia, enteropathogenic strains of Escherichia coli, or some Bacillus and Clostridium species.

An important component of the effect of lactic acid bacteria on animal bodies is their capacity for anaerobic fermentation of simple sugars, disaccharides, and some oligo- and polysaccharides in the digestive mucosa to lactic acid (Simon et al., 2001). Both acids acidify the digesta environment by reducing the $\mathrm{pH}$ of intestinal digesta, which limits the colonization of pathogenic bacteria in the digestive tract. An important feature of lactic acid bacteria is their ability to synthesize bacteriocins, substances that exhibit antibacterial activity (Klaenhaemmer, 1993; Joerger, 2003). Bacteriocins are protein substances produced and secreted by bacterial cells, with bactericidal activity against microorganisms, consisting of only 17 to 37 amino acids (Joerger, 2003). They have been attributed with the ability to eliminate pathogenic bacteria from the digestive tract. Many research studies have documented the inhibitory effect of probiotics on the development of pathogenic microorganisms (Clostridium, Shigella, Salmonella, Escherichia coli, Listeria monocytogenes) and rotaviruses, the associated incidence of diarrhoea, and on ameliorating the course of diarrhoea (Gaenzle et al., 1999; Rolfe, 2000). Śliżewska et al. (2006) suggest that following bacterial fermentation of sugars, lactic acid is partly dissociated, while the undissociated form passes through lipid cell membranes and by dissociating within the cell, it acidifies cell contents and inhibits the growth of pathogenic microorganisms, including putrefactive bacteria, Gram-negative bacteria, and also some moulds. The same authors hold that lactic acid can be further fermented into acetic acid, which neutralizes electrochemical cell potential and can decrease the growth of putrefactive bacteria, including those of the genera Clostridium and Salmonella. Bacteria of the genera Lactobacillus, Enterococcus faecium, Lactococcus lactis and Streptococcus thernophilus are the main producers of bacteriocins (Śliżewska et al., 2006). The bacteriocin nisin has received GRAS (generally recognized as safe) status under 21 CFR 184.1538. Produced by lactic acid bacteria, it has an important role in fermented milk products for humans and in lyophilized feed additives for animals (Joerger, 2003).

Probiotic bacteria show affinity to, and colonize, specific parts of the digestive tract, including crop, duodenum, small intestine and caecum (Hamer, 2002). This 
may be associated with their different tolerance to digesta $\mathrm{pH}$ in different segments of the digestive tract. Lactic bacteria tolerate a low $\mathrm{pH}$ of $3-4$, and the optimum growth temperature is $20-28^{\circ} \mathrm{C}$ in mesophilic species and $37-45^{\circ} \mathrm{C}$ in thermophilic species. Because food mass leaving the stomach has a $\mathrm{pH}$ of about $2-3$, resistance of probiotic bacteria to such low $\mathrm{pH}$ is essential.

Lactococcus Spp. bacteria are widely used in the manufacture of milk products. Their probiotic abilities are not adequately studied.

Research showed that compared to Lactobacillus delbruecki 838 and Lactobacillus plantarum 837, Lactococcus lactis 838 bacteria create no significant differences in chickens' body weight, feed consumption and feed conversion. This means that Lactococcus Spp. bacteria, just like Lactobacillus Spp., do not interfere with nutrient bioavailability, metabolism and use for tissue and organ growth. Probiotic bacteria produce enzymes that degrade unavailable carbohydrates such as betaglucans, and increase beta-galactosidase, saccharose and maltase activity (Yu et al., 2008). In light of the research conducted, it is difficult to determine if these effects are translated into feed conversion and carcass quality. The present study was conducted in the presence of prebiotic mannan oligosaccharide and acidifier, which was also present in the control group without lactic bacteria. When both factors were not used in the broiler diets, probiotic bacteria significantly increased chickens' body weight (Brzóska and Stecka, 2007). However, we acknowledged that new strains of probiotic bacteria for birds should be tested in the presence of prebiotics and acidifiers, because both these factors are now widely used in poultry nutrition.

It was found that bacteria such as Lactococcus lactis 847, Lactobacillus delbruecki 838 and Lactobacillus plantarum 837 significantly reduce avian mortality compared to the control group receiving no bacteria in the diet. This fact may suggest that they have probiotic effects on chicken bodies regardless of whether prebiotic and acidifier, which were present in the control group receiving no lactic acid bacteria, were used or not.

Research results also showed a significant effect of Lactococcus lactis 847 and Lactobacillus plantarum 837 bacteria on increasing dressing percentage in chickens in relation to the control group of birds. The group receiving Lactobacillus delbruecki 838 had no effect on dressing percentage in chickens. Feeding lactic acid bacteria to the chickens resulted in no significant differences in slaughter weight, the weight of individual saleable cuts and their proportion in carcass weight. These results are consistent with those of earlier studies which used mixtures of Lactobacillus paracasei KKP 824, Lactobacillus rhamnosus KKP 825 and KKP 826 bacteria, and agree with the findings of other authors (Brzóska and Stecka, 2007). A small (1-2\%) increase in chickens' body weight was obtained when probiotic bacteria Pediococcus Spp. were used together with mannan oligosaccharide as a prebiotic and acidifier (Brzóska et al., 2010). In other studies, feeding broiler chickens a probiotic containing 5 strains of bacteria isolated from different segments of the digestive tract of healthy chickens - Lactobacillus reuteri DSM 16350 (crop), Enterococcus faecium DSM 16211 (jejunum), Bifidobacterium animalis DSM 16284 (ileum), Pediococcus acidilactici DSM 16210 and Lactobacillus salivarius DSM 16351 (caecum) at $10^{8} \mathrm{cfu} / \mathrm{kg}$ feed caused a small but significant increase in body weight and significantly increased nu- 
trient digestibility (Mountzouris et al., 2010). The results reported above suggest that a positive effect of lactic acid bacteria on nutrient digestibility can be obtained when the diet of chickens contains bacteria that show affinity to specific parts of the digestive tract. In light of previous studies, it is difficult to explain the decrease in liver weight of chickens receiving Lactobacillus plantarum 837 bacteria, because lactic acid bacteria had been shown to exert no significant effect on liver metabolism.

Feeding probiotic bacteria to the chickens did not create any differences in dry matter, protein and fat content of breast muscles, which is confirmed by many previous studies and suggests that probiotic bacteria do not interfere with the basal metabolism of protein and fat in avian bodies (Kalavathy et al., 2003). These traits are genetically determined, and feed additives and bacterial dietary supplements did not result in any significant differences in the components of chicken muscle tissue studied. Therefore, the action of probiotic bacteria should be limited exclusively to the digestive tract as a specific ecological niche, in which various microorganisms live under anaerobic conditions and find favourable conditions for growth.

No significant differences were found in plasma levels of glucose, total protein and total cholesterol in different groups of chickens. Significant differences occurred in the level of triglycerides. Chickens receiving Lactobacillus plantarum 837 had significantly lower plasma triglyceride levels, corresponding to significantly lower liver weight. If we assume that triglycerides are partly derived from dietary fat and absorbed by lymph, and partly synthesized in the liver, this relationship seems understandable, although the research conducted does not allow explaining it in detail.

The examination of chicken carcass quality depending on sex of birds confirms the often reported significant relationships between higher weight of male bird carcasses and different saleable cuts and organs, including the higher fatness of female carcasses, which was reported in many studies (Acar et al., 1993; Brake et al., 1993; Young et al., 2001). The differences described above can be attributed to the different hormonal systems of male and female broiler chickens. Male testosterone stimulates the growth of bone and muscle tissue weight more than carcass fatness, unlike female estrogens, which are responsible for lower bone growth and higher content of depot fat in the body cavity. Male birds had significantly higher plasma levels of glucose and cholesterol, which could be attributed to the different effects of sex hormones on avian bodies.

Based on this study, it can be concluded that similar to Lactobacillus delbruecki 838 and Lactobacillus plantarum 837, Lactococcus lactis 847 bacteria have similar effects on the body of broiler chickens. These effects have the characteristics of probiotic activity, which limits chicken mortality, but do not create significant differences in carcass weight, saleable cuts, composition of muscle tissue, and plasma metabolic parameters.

\section{References}

A c a r N., Moran E.T. jr, Mulvaney D.R. (1993). Breast muscle development of commercial broilers from hatching to twelve weeks of age. Poultry Sci., 72: 317-325. 
AOAC. (1990). Official Methods of Analysis. Association of Official Analytical Chemists, Arlington, VA, USA, 15 th Ed.

Brake J., Havenstein G.B., S cheideler S.E., Ferket P.R., Rives V. (1993). Relationship of sex, age, and body weight to broiler carcass yield and offal production. Poultry Sci., 72: 1137-1145.

Brzóska F., Grzybowski R., Stecka K., Pieszka M. (1999). Nutritive value of selected probiotic microorganisms in chicken broilers. Ann. Anim. Sci., 26: 291-301.

Brzó s k a F., B u l u c h e vs kij S.B., Śliwińs ki B., S t e c k a K. (2005). Preliminary study of the microbial spectrum of digestive tract in broilers fed diets with and without antibiotic supplementation. J. Anim. Feed. Sci., 14: 431-434.

B rzós k a F., S te ck a K. (2007). Effect of probiotic, prebiotic and acidifier on the body weight of broiler chickens, feed conversion, and carcass and meat composition. Ann. Anim. Sci., 7: 279-288.

Brzóska F., Pieszka M., Stecka K., Migdał W., Węsierska E., Walczycka M., Krzysztoforski K., M i chalik-Rutkowska O. (2010). Effect of Pediococcus Spp. instead of antibiotic on broiler chicken body weight, mortality, slaughter traits and meat quality. Ann. Anim. Sci., 10: 167-177.

C oc onnier M.H., Li e vin V., H e mery E., S e rv in A.L. (1998). Antagonistic activity against Helicobacter infection in vitro and in vivo by the human Lactobacillus acidophilus strain LB. Appl. Environ. Microbiol., 64: 4573-4580.

F u lle r R. (1989). Probiotics in man and animals. J. Apl. Bacteriol., 66: 365-378.

Gaenzle M., Hertle J.M., Van der Vossen B.M., Hammes W.P. (1999). Effect of bacteriocin-producing lactobacilli on the survival of Escherichia coli and Listeria monocytogenes in a dynamic model of the stomach and small intestine. Int. J. Food Microbiol., 48: 21-35.

G h a d b a n G.S. (2002). Probiotics in broiler production - A review. Arch. Geflugelkd., 66: 49-58.

Grela E., Semeniuk W. (1999). Probiotic in animal production (in Polish). Med. Weter., 55: 222-228.

Grzybowski R.A., S tecka K.M., Szkudzińska-Rzekowiak E.A., Milewski J.A. (1998). Milk fermentative bacteria as component of probiotic additives. In: Milk fermentative bacteria. Classification, metabolism, genetic, utilization. Eds: Z. Libudzisz, P. Walczak, J. Badowski. Edition by Lodz Institute of Technology, pp. 98-121.

H a m e r D.H. (2002). From farm to the kitchen table: the negative impact of antimicrobial use in animals on humans. Nutr. Rev., 60: 261-264.

J o e r g e r R.D. (2003). Alternatives to antibiotics: bacteriocins, antimicrobial peptides and bacteriophages. Poultry Sci., 82: 640-647.

Kabit A.M.A., A ib a Y., Takagi A., Kamiya S., Miwa T., Kog a Y. (2007). Prevention of Helicobacter pylori infection by lactobacilli in a gnotobiotic murine model. Gut, 41: 49-55.

Kalavathy R., Abdullah N., Jalaludin S., Ho Y. (2003). Effects of Lactobacillus cultures on growth performance, abdominal fat deposition, serum lipids and weight of organs of broiler chicken. Brit. Poultry Sci., 44: 139-144.

$\mathrm{K} l \mathrm{l}$ e $\mathrm{n}$ h a e m m e r T.R. (1993). Genetics of bacteriocins produced by lactic acid bacteria. FEMS Microbiol. Rev., 12, 39-85.

Koenen M.E., Kramer J., van der Hulst R., Heres L., Jeurissen S.H.M., B o e r s m a W.J.A. (2004). Immunomodulation by probiotic Lactobacilli in layer- and meat-type chicken. Brit. Poultry Sci., 45: 355-366.

McCracken V.J., Gaskins H.R. (1999). Probiotics and the immune system. In: Probiotics: A critical review. Ed. Tannock G., Horizon Scientific Press, UK, pp. 85-112.

Mountzouris K.C., Tsitrsikos P., Palamidi I., Arvaniti A., Mohnl M., Schatzm a y r G., F e ge r o s K. (2010). Effect of probiotic inclusion levels in broiler nutrition on growth performance, nutrient digestibility, plasma immunoglobulins, and cecal microflora composition. Poultry Sci., 89: 58-67.

P ros t E.K. (1999). Probiotics (in Polish). Med. Weter., 55: 75-79.

$\mathrm{R}$ a ft e r J. (1995). The role of lactic acid bacteria in colon cancer prevention. Scand. J. Gastroenterol., 30: 497-502.

R o $1 \mathrm{fe}$ R.D. (2000). The role of probiotic cultures in the control of gastrointestinal health. J. Nutr., 130: 396S-402S. 
S a arela M., Mogensen G., Fonden R., Matto J., Matitila-Sandholm T. (2000). Probiotic bacteria safety, functional and technological properties. J. Biotechnol., 84: 197-215.

$\mathrm{S}$ i m on O., J a d a m u s A., V a h j e n W. (2001). Probiotic feed additives - effectiveness and expected modes of action. J. Anim. Feed. Sci., 10, Suppl., 1: 51-67.

Śliżewska K., B i ernasiak J., Libudzisz Z. (2006). Probiotics as alternative for antibiotics (in Polish). Zesz. Nauk. Politechniki Łódzkiej, 984: 79-91.

Vitini E., Alvarez S., Medina M., Medici M., de Budeguer M.V., Perdigon G. (2001). Gut mucosal immunostimulation by lactic acid bacteria. Biocell, 24: 223-232.

Y oung L.L., Northcutt J.K., Buhr R.J., L y o n C.E., W a r e G.O. (2001). Effect of age, sex, and duration of postmortem aging on percentage yield of parts from broiler chicken carcasses. Poultry Sci., 80: 376-379.

Y u B., L i u J.R., H s i a o F.S., C h i o u P.W.S. (2008). Evaluation of Lactobacillus reuteri Pg4 strain expressing heterologous $\beta$-glucanase as a probiotic in poultry diets based on barley. Anim. Feed Sci. Technol., 141: 82-91.

Z gło b i c a A., R ó ż y c k a B. (1972). Chicken carcass slaughter methods (in Polish). Ed. by Ministry of Agriculture and Forestry. Warszawa, pp. 72-85.

Accepted for printing 5 III 2012

\title{
FRANCISZEK BRZÓSKA, BOGDAN ŚLIWIŃSKI, KRYSTYNA STECKA
}

\author{
Wpływ bakterii Lactococcus lactis vs. Lactobacillus Spp. na masę ciała, śmiertelność kurcząt \\ rzeźnych oraz wykorzystanie paszy, skład i jakość tuszek
}

\section{STRESZCZENIE}

Badania wykonano na 608 kurczętach rzeźnych broilerach obu płci ROSS 308. Badano wpływ podawania diety zawierającej bakterię Lactococcus lactis $847 \mathrm{w}$ porównaniu do diety z bakterią probiotyczną Lactobacillus delbruecki 838 i Lactobacillus plantarum 837 na masę ciała, spożycie i wykorzystanie paszy, śmiertelność, wydajność rzeźną, cechy poubojowe tuszek i skład tkanki mięśni piersiowych oraz cechy osocza krwi. Doświadczenie wykonano na 4 grupach kurcząt, po 4 powtórzenia. Kurczęta żywiono dietą kukurydziano-pszeniczno-sojową. Bakterie probiotyczne podawano 6-krotnie w czasie 42 dni chowu, w ilości 4 mln komórek bakteryjnych/ptaka, w wodzie pitnej.

Podawanie kurczętom diety z bakteriami nie zwiększyło masy ciała kurcząt w 42. dniu życia w porównaniu do kurcząt grupy kontrolnej nieotrzymujących bakterii. Obniżyło istotnie śmiertelność kurcząt w porównaniu do grupy kontrolnej z 3,3\% do 1,4\% (P<0,01). Nie stwierdzono istotnych różnic w spożyciu i wykorzystaniu paszy. Nie stwierdzono istotnych różnic w masie tuszek i poszczególnych jej elementach. Bakterie Lactobacillus delbruecki 838 i Lactobacillus plantarum 837 istotnie zwiększyły wydajność rzeźną ( $\mathrm{P}<0,05)$. Bakteria Lactococcus lactis 847 istotnie zwiększyła masę wątroby $(\mathrm{P}<0,05)$. Nie stwierdzono istotnych różnic w otłuszczeniu tuszek. Nie stwierdzono istotnych różnic w zawartości suchej masy, białka i tłuszczu w mięśniach piersiowych. Podawanie kurczętom bakterii Lactobacillus plantarum 837 istotnie obniżyło poziom trójglicerydów w osoczu krwi kurcząt, a obu bakterii Lactobacillus delbruecki 838 i Lactobacillus plantarum 837 poziom cholesterolu ogólnego i cholesterolu wysokocząsteczkowego $(\mathrm{P}<0,05)$. Wnioskowano, że bakterie Lactococcus lactis 847 istotnie obniżają straty powodowane schorzeniami przewodu pokarmowego w porównaniu do grupy bez bakterii, na poziomie podobnym do grup brojlerów otrzymujących dietę z bakteriami Lactobacillus delbruecki 838 i Lactobacillus plantarum 837, stąd można je uznać za bakterie probiotyczne. 